\title{
Intracystic Papillary Neoplasm of the Gallbladder Arising from a Localized Adenomyomatous Hyperplasia
}

\author{
Hyeong Seok Nam¹, Dae Hwan Kang ${ }^{1}$, Byung Hyun $\mathrm{Choi}^{2}$, So Young Kim³, Jung Hee Lee \\ 'Department of Internal Medicine, Pusan National University School of Medicine and Research Institute for Convergence of Biomedical Science \\ and Technology, ${ }^{2}$ Division of Hepato-Biliary-Pancreatic Surgery and Transplantation, Department of Surgery, ${ }^{3}$ Department of Pathology, Pusan \\ National University Yangsan Hospital, Pusan National University School of Medicine, Yangsan, Korea
}

Adenomyomatous hyperplasia (AMH) of the gallbladder commonly accompanies chronic cholecystitis and may be classified into three types according to the gross features: segmental, localized (fundal), and diffuse types. In situ or invasive carcinomas arising from and confined to $\mathrm{AMH}$ are rarely observed, especially of the segmental type. Intracystic papillary neoplasm (IPN) is one of the precancerous lesions of the gallbladder. IPN usually grows into the lumen and produces a polypoid or papillary mass. Here, we report an extremely rare case of IPN arising from and limited to a localized AMH incidentally detected in a brain-dead 68-year-old female patient during organ harvesting.

Korean J Pancreas Biliary Tract 2018;23(4):182-189

Keywords: Adenomyomatous hyperplasia, Adenomyomatosis, Papillary neoplasm, Gallbladder $\begin{array}{lr}\text { Received } & \text { Aug. 10, } 2018 \\ \text { Revised } & \text { Sep. 17, } 2018 \\ \text { Accepted } & \text { Sep. 20, 2018 }\end{array}$

Corresponding author: Jung Hee Lee

Department of Pathology, Pusan National University Yangsan Hospital, 20 Geumo-ro, Mulgeum-eup, Yangsan 50612, Korea

Tel. +82-55-360-1859 Fax. +82-55-360-1865

E-mail; 4unii@hanmail.net

ORCID: https://orcid.org/0000-0003-3003-2217

This is an Open Access article distributed under the terms of the Creative Commons Attribution Non-Commercial License (http:/ creativecommons.org/licenses/by-nc/3.0/) which permits unrestricted non-commercial use, distribution, and reproduction in any medium, provided the original work is properly cited.

Copyright $\odot 2018$ by The Korean Journal of Pancreas and Biliary Tract

\section{INTRODUCTION}

Adenomyomatous hyperplasia (AMH) is commonly identified in the gallbladders with chronic cholecystitis and gallstones. $\mathrm{AMH}$ is defined by invaginations of the surface epithelium into the subserosa (Rokitansky-Aschoff sinus, RAS) accompanied by smooth muscle hyperplasia. ${ }^{1}$ A RAS develops through the gaps in the smooth muscle layer of the gallbladder wall. Three types of AMH are described according to the gross features: segmental, localized (fundal), and diffuse types. ${ }^{2}$ Segmental AMH has a greater association with cancer development than the other types. ${ }^{2-4}$ In situ or invasive carcinomas that directly originate from and are confined to $\mathrm{AMH}$ are rarely observed, especially of the segmental type. ${ }^{5-9}$ We have provided a comparison of these rare cases. None of them involved a neoplasm derived from a localized AMH.

Intracystic papillary neoplasm (IPN) is one of the precancerous lesions of the gallbladder. ${ }^{10}$ IPN has been referred as “intracholecystic papillary-tubular neoplasm”, "papillary adenoma”, "tubulopapillary adenoma”, "papillary neoplasm”, 
and so on. ${ }^{11}$ IPN is composed of preinvasive neoplastic (dysplastic) cells in a papillary configuration and has characteristics similar to those of intraductal papillary mucinous neoplasm (IPMN) of the pancreas. IPN forms morphologically identifiable, intraluminally growing tumors. Here, we report an extremely rare case of IPN arising from and limited to a localized AMH incidentally detected in a brain-dead patient during organ harvesting.

\section{CASE}

A 68-year-old female underwent a decompressive craniotomy for subdural hematoma after experiencing a head injury. The patient stayed unconscious despite surgery and was confirmed brain death. Her organs were to be donated including the liver and kidney. During organ harvesting, the surgeons detected a cystic lesion in the fundus of the gallbladder and performed cholecystectomy for an intraoperative pathologic examination. The patient had no history of significant illness except use of medications for diabetes, hypertension, and hyperlipidemia. Preoperative abdominal ultrasonography showed gallstones and bilateral renal cysts (up to $1.0 \mathrm{~cm}$ ), but no other abnormalities.

Grossly, the gallbladder was tensely distended and filled with bile and stones. A dome-shaped cystic mass, $1 \mathrm{~cm}$ in size, was identified on the serosal surface of the gallbladder fundus (Fig. 1). The mass was elevated on the mucosal surface with eccentric umbilication. The cut surface of the mass had a spongy appearance and had no solid component. The gallbladder wall did not show thickening elsewhere. A localized $\mathrm{AMH}$ was suspected based on these gross findings.

Microscopically, the mass was reminiscent of the gastric type of IPMN of the pancreas (Fig. 2). The pancreas was examined by intraoperative ultrasonography and revealed no mass. The IPMN-like mass was composed of multiple dilated cysts with papillary growth in the subserosal layer. The cysts were lined by tall columnar cells with basally located nuclei and abundant intracellular mucin. There was no stromal invasion but focal nuclear atypia was observed in the cyst-lining epithelial cells. The mitotic figure was not observed. The gallbladder mucosa had invaginated vertically into the

Table 1. Specification of the antibodies

\begin{tabular}{lccc}
\hline Antibody & Clone & Dilution & Source \\
\hline MUC5AC & MRQ-19 & $1: 200$ & CellMarque \\
MUC6 & CLH5 & $1: 300$ & Novocastra \\
\hline CK7 & OV-TL 12/30 & $1: 100$ & Novocastra \\
CK19 & RCK108 & $1: 100$ & DAKO \\
CDX2 & EPR2764Y & $1: 400$ & CellMarque \\
MUC2 & CCp58 & $1: 300$ & Novocastra \\
CK20 & Ks20.8 & $1: 25$ & DAKO \\
Ki-67 & MIB-1 & $1: 600$ & DAKO \\
P53 & D0-7 & $1: 800$ & Novocastra \\
SMAD4 & B-8 & $1: 400$ & Santa cruz \\
\hline
\end{tabular}

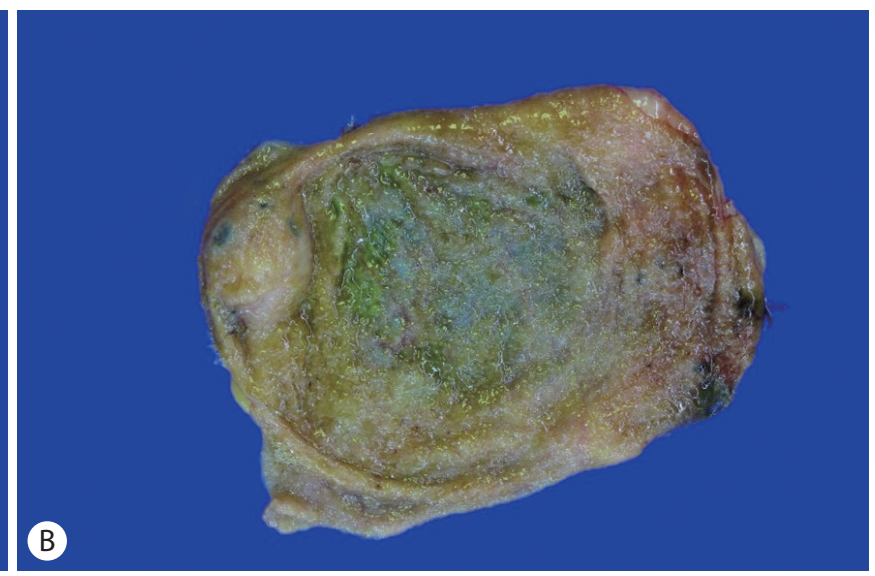

Fig. 1. (A) The cholecystectomy specimen shows a dome-shaped cystic mass on the serosal surface at the tip of the fundus (arrow). (B) A polypoid or papillary lesion is not identified on the mucosal surface. 
mass along with the smooth muscle layer (indicated by the solid line in Fig. 2A). This mucosal invagination corresponded with the umbilication seen in the gross examination. The leading point of the mucosal invagination from which the IPMN-like mass seemed to radiate was located in the center of the thickened gallbladder wall. RASs were haphazardly distributed around the mass. One of the RASs showed a transition to IPMN-like epithelium (Fig. 2D). Another one was filled with inspissated bile. We diagnosed the present case as an intracystic papillary neoplasm with high grade dysplasia (in situ carcinoma) arising from and confined to a localized AMH. Since stromal invasion was not observed, the organs were donated as planned.

After the frozen section diagnosis, immunohistochemistry was performed using the Dako Envision method (Dako, Glostrup, Denmark) and primary antibodies listed in Table 1. The results of immunohistochemistry are summarized in Table 2. The gastric mucins (MUC5AC and MUC6) were expressed in the tumor cells (Fig. 3) whereas the biliary markers (CK7 and CK19) had a slightly weaker expression in the tumor cells than in the adjacent epithelium. The intestinal markers (CDX2 and MUC2) in tumor cells showed negative response. Interestingly, CK20 and Ki-67 expression was observed in the densely packed tubular
(A)
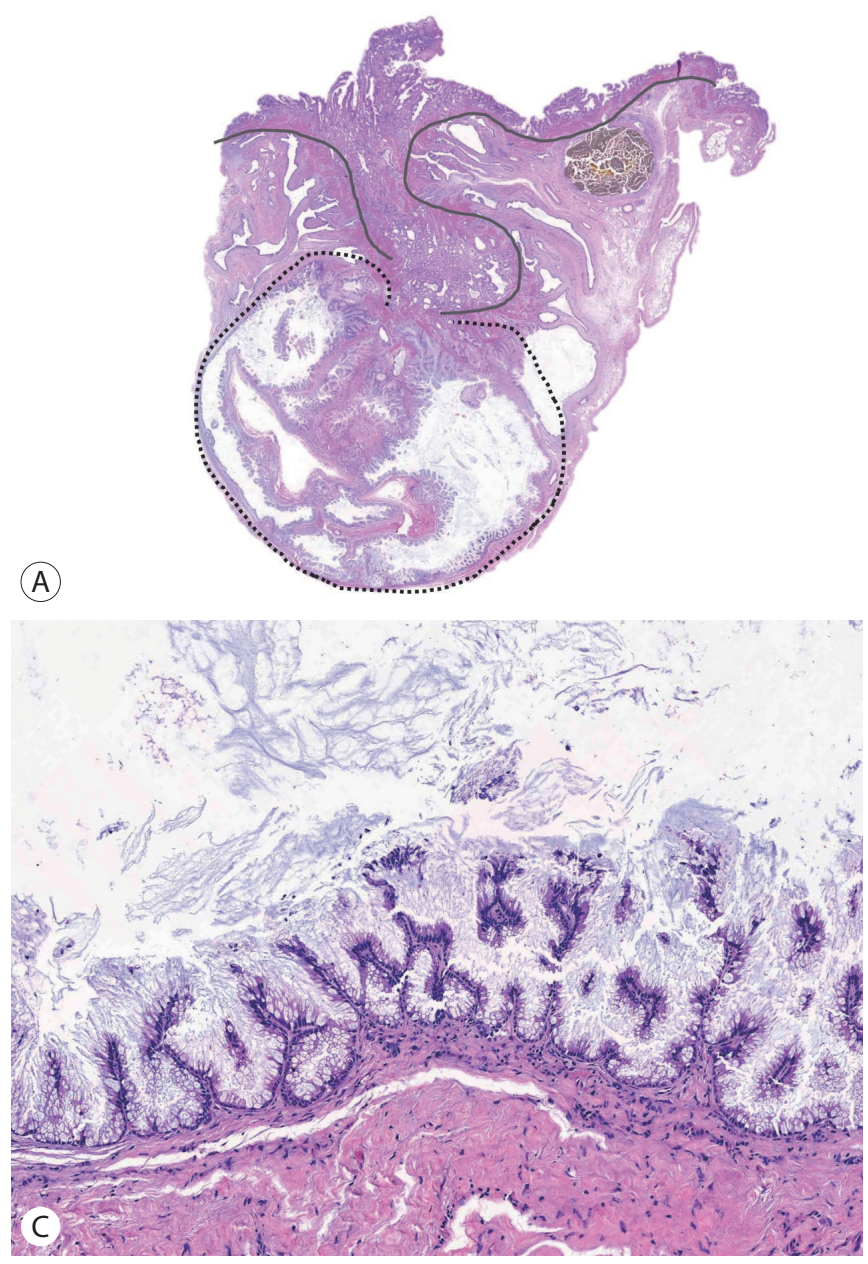
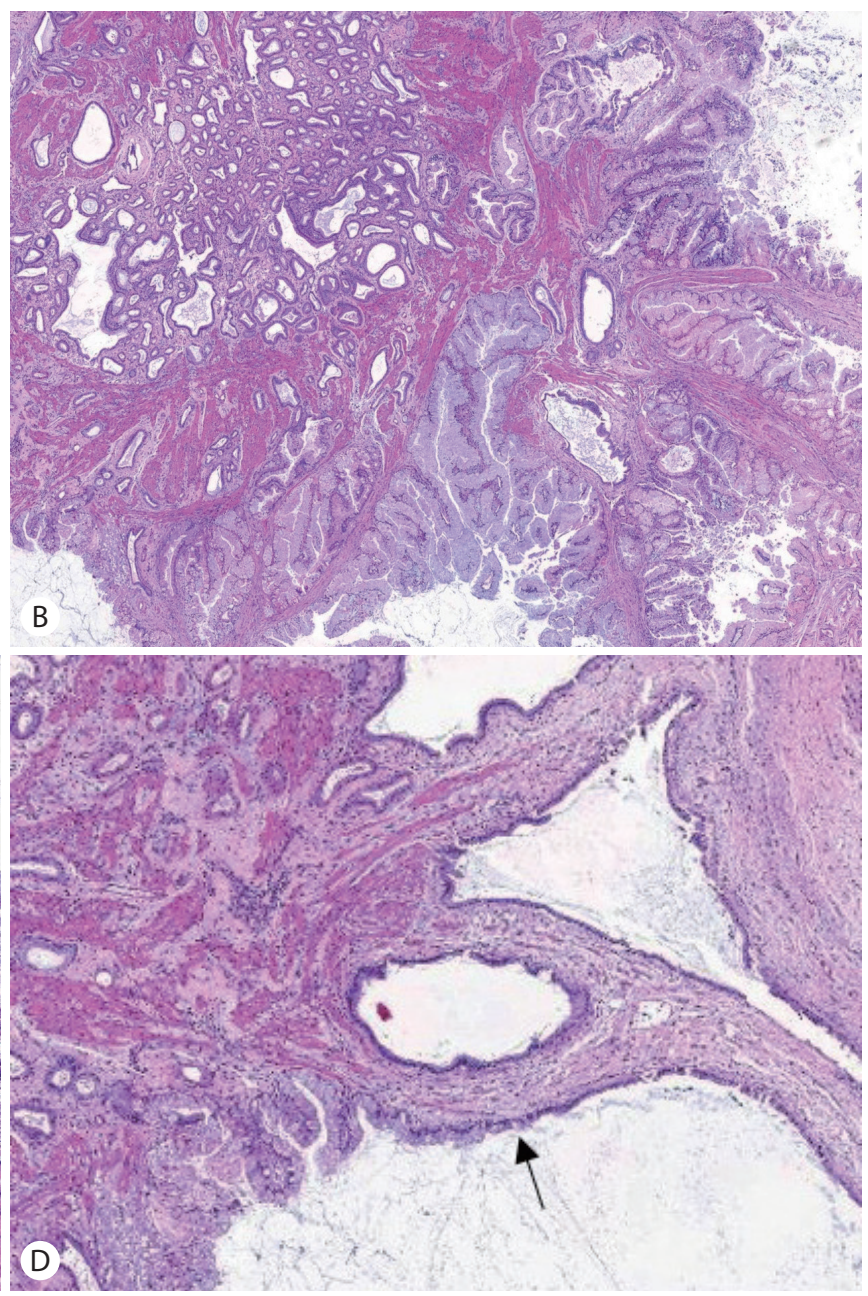

Fig. 2. (A) Microscopic findings show a subserosal cystic neoplasm encircled by the dotted line. The gallbladder mucosa is invaginated with smooth muscle layer (indicated by the solid line) into the cystic neoplasm. (B) At the end of the mucosal invagination, small tubular structures are crowded (right upper). (C) The neoplastic cysts are lined by tall columnar epithelial cells with abundant cytoplasmic mucin and papillary growth. (D) There is a transition from non-neoplastic cuboidal cells to neoplastic tall columnar cells along the Rokitansky-Aschoff sinus wall (arrow). 
structures between the invaginating surface epithelium and the tumor. The tumor also showed increased Ki-67 labeling compared to the RASs and normal surface epithelium. However, p53 positivity and distinct loss of SMAD4 expression were not observed in the tumor. There was no KRAS mutation (Fig. 4).

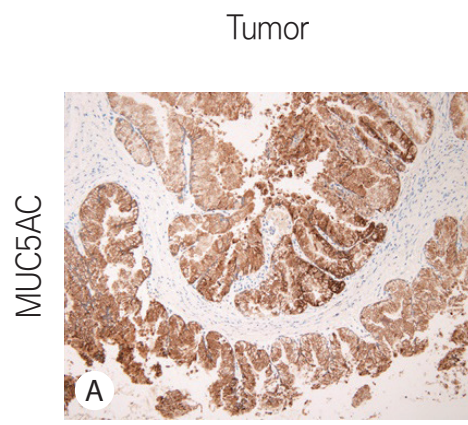

Crowded small tubular struc-
tures

Rokitansky-Aschoff sinuses
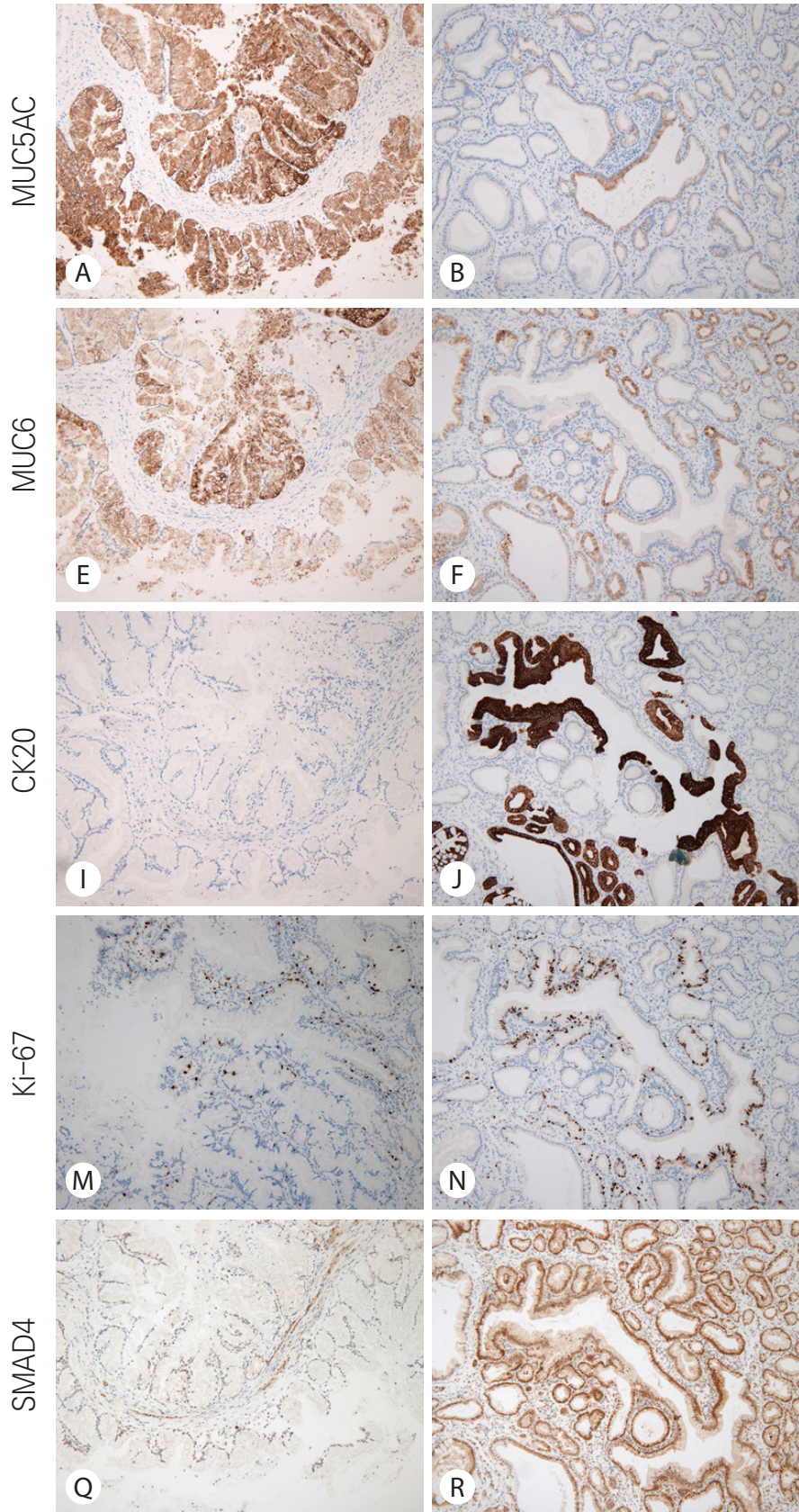
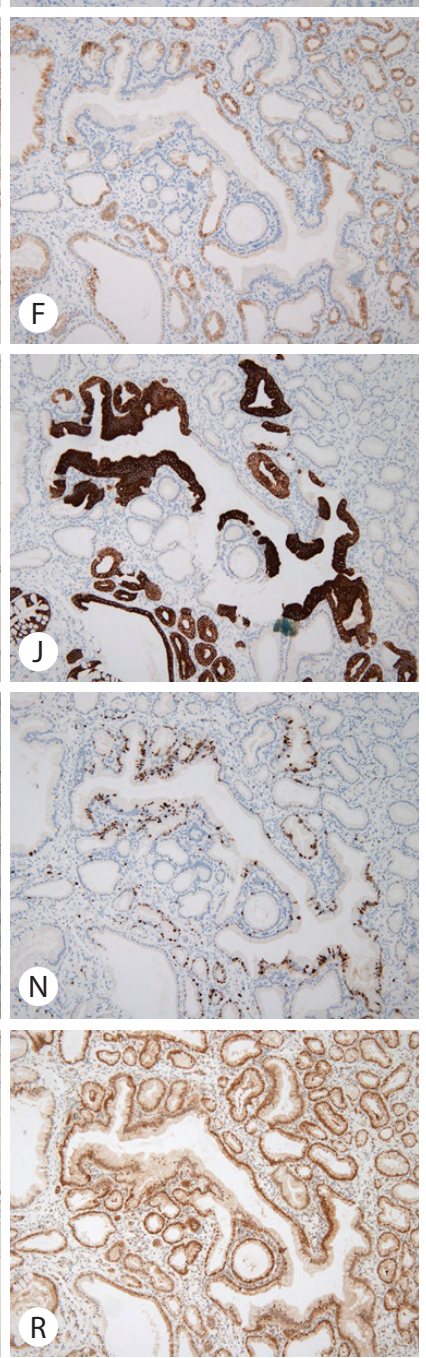
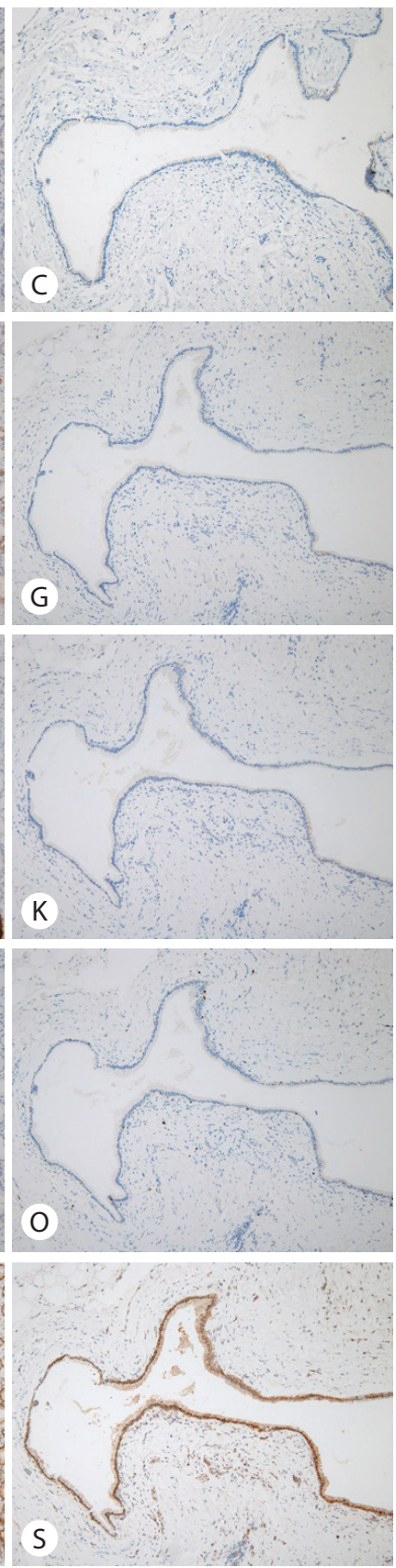

Surface epithelium
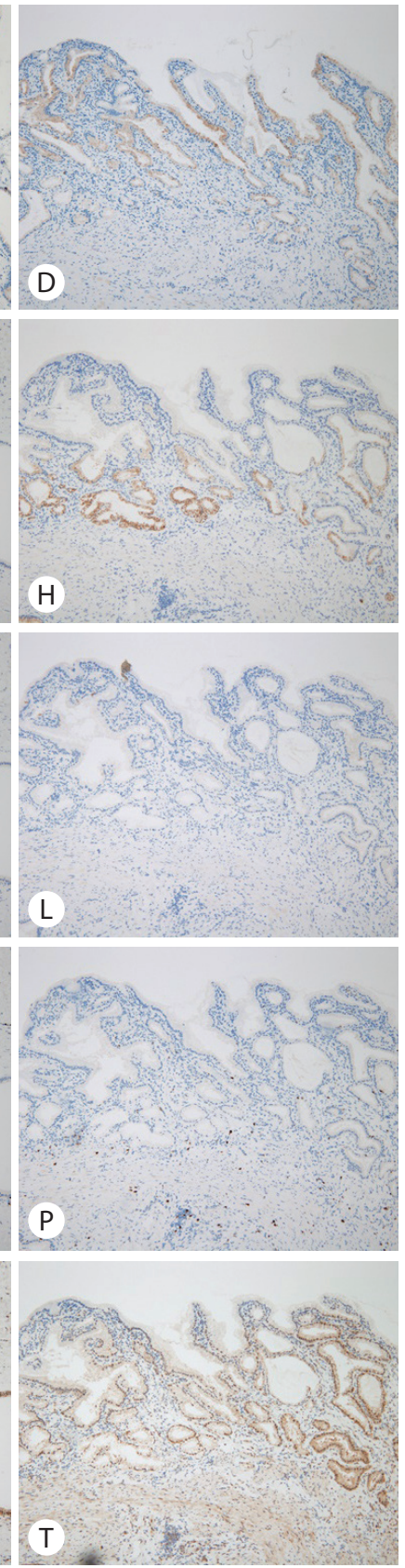

Fig. 3. Comparison of immunohistochemical reaction among tumor, crowded small tubular structures, Rokitansky-Aschoff sinuses, and surface epithelium in the present case. The tumor shows relatively strong reaction to MUC5AC and MUC6, and faint loss of expression of SMAD4. Crowded small tubular structures exhibit CK20 immunoreactivity and increased Ki-67 labeling (A-D: MUC5AC, ×100; E-H: MUC6, ×100; I-L: CK20, ×100; M-P: Ki-67, ×100; Q-T:SMAD4, $\times 100)$. 


\section{DISCUSSION}

During performing surgery, surgeons occasionally encounter unexpected tumors in a patient's organs despite the preoperative evaluation. Prompt inspection through intraoperative pathologic examination helps to determine whether to proceed with, cancel, or extend the surgery. The gallbladder is one of the organs that commonly show worrisome findings such as a polyp or focal wall thickening during an operation. Because of the increasing number of both elderly people and laparoscopic cholecystectomies, clinicians and pathologists should become familiar with the pseudoneoplastic and neoplastic gallbladder lesions associated with chronic cholecystitis.

Pseudodiverticula known as RAS are very common in chronic cholecystitis and may display reactive epithelial atypia, which may be mistaken for invasive carcinoma. ${ }^{12}$ The zonal contraction impeding full relaxation and increased intraluminal pressure are considered to be the possible causes of RAS. ${ }^{13}$ When smooth muscle hyperplasia accompanies RAS, the terms AMH or adenomyomatosis are used. AMH occurs in approximately 5\% of cholecystectomy specimens. According to the gross features, $\mathrm{AMH}$ is classified into three types: segmental (67\%), localized (fundal) (30\%), and diffuse types $(3 \%))^{2}$ The segmental type of $\mathrm{AMH}$ is characterized by an annular stricture composed of a thickened wall that
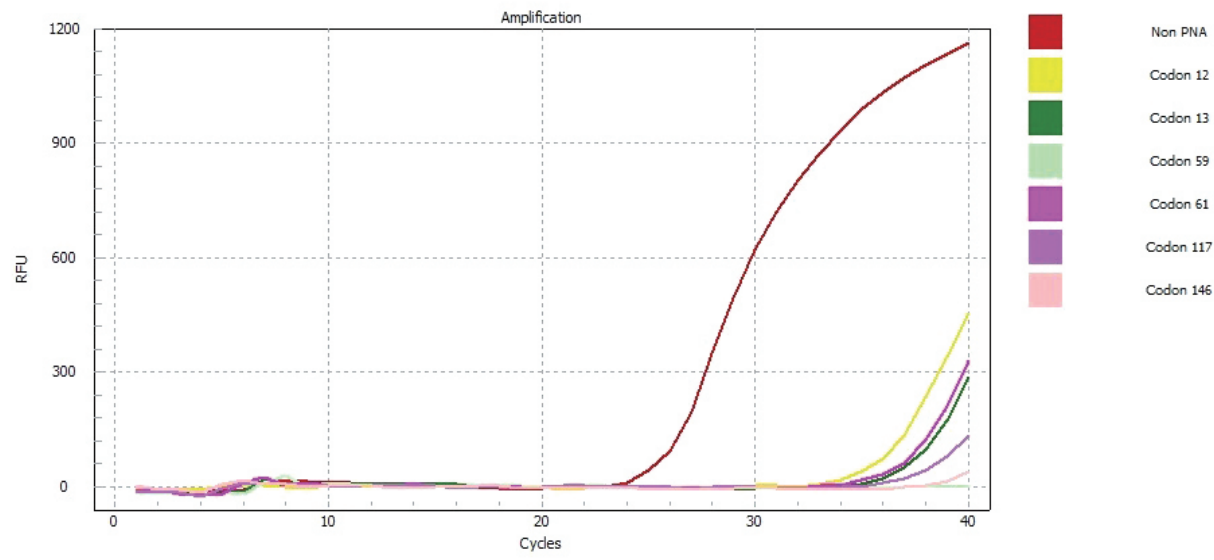

Fig. 4. KRAS mutation is not detected through a PNA clamp PCR assay. RFU, relative fluorescence units; PNA, peptide nucleic acid; $P C R$, polymerase chain reaction.

Table 2. Comparison of the immunohistochemical reaction among tumor, crowded small tubular structures, Rokitansky-Aschoff sinuses, and surface epithelium in the present case. The tumor shows relatively strong reaction to gastric mucins (MUC5AC and MUC6), and faint loss of expression of SMAD4. The crowded small tubular structures exhibit CK20 immunoreactivity and increased Ki-67 labeling

\begin{tabular}{|c|c|c|c|c|}
\hline Antibody & Tumor & $\begin{array}{l}\text { Crowded small tubular } \\
\text { structures }\end{array}$ & $\begin{array}{l}\text { Rokitansky-Aschoff } \\
\text { sinuses }\end{array}$ & Surface epithelium \\
\hline MUC5AC & +++ & + & - & + \\
\hline MUC6 & ++ & + & - & + \\
\hline CK7 & ++ & +++ & +++ & +++ \\
\hline CK19 & + & ++ & ++ & ++ \\
\hline $\mathrm{CDX} 2$ & - & $+/-$ & - & - \\
\hline MUC2 & $+/-$ & - & - & $+/-$ \\
\hline CK20 & - & +++ & - & $+/-$ \\
\hline Ki-67 labeling & $10 \%$ & $30 \%$ & $1 \%$ & $0 \%$ \\
\hline p53 & - & - & - & - \\
\hline SMAD4 & Faint loss of expression & $\begin{array}{c}\text { Absence of loss of } \\
\text { expression }\end{array}$ & Absence of loss of expression & $\begin{array}{l}\text { Absence of loss of } \\
\text { expression }\end{array}$ \\
\hline
\end{tabular}


divides the gallbladder lumen into separate interconnected compartments ("hourglass" appearance). The localized (fundal) type of AMH appears as a hemispheric elevated lesion with a central dimple, located at the tip of the gallbladder and is also called as an adenomyoma. The diffuse type of AMH occurs throughout the entire gallbladder as wall thickening. Segmental AMH is highly related to gallbladder carcinoma. ${ }^{2-4}$ Approximately $6.5 \%$ of patients with segmental AMH had gallbladder cancer synchronously. On the other hand, the localized (fundal) and diffuse AMH seem to have no relation to gallbladder carcinoma. ${ }^{14}$

IPN of the gallbladder is in similar spectrum of intraductal papillary neoplasm of the bile duct (intrahepatic or extrahepatic), intraductal papillary mucinous neoplasm or intraductal tubulopapillary neoplasm of the pancreas, and intraampullary papillary-tubular neoplasm of the ampulla. ${ }^{12}$ IPN is an intraepithelial neoplasia with a papillary pattern accompanied with or without mucin production. IPN of the gallbladder defined as $\geq 1.0 \mathrm{~cm}$ were uncommon with the frequency of $0.4 \%$ among cholecystectomies. On the basis of the predominant pattern ( $>75 \%$ of the lesion) on the histological morphology and supporting immunohistochemical cell lineage markers, IPN is subclassified as biliary in 50\% (MUC1+), gastric in 36\% (MUC5AC+ and MUC6+), intestinal in $8 \%(\mathrm{CK} 20+)$, and oncocytic in 6\%. Fifty five percent of the overall cases had an associated invasive carcinoma (biliary type, $47 \%$; others, $8 \%$ ).
We performed the immunohistochemical study to confirm the gastric type of the presenting IPN (MUC5AC+, MUC6+, and CK20-) and to exclude the high-risk factors associated with tumor progression (p53-, no loss of SMAD4 expression, and low Ki-67 labeling). The adjacent areas including crowded small tubular structures, RAS, and surface epithelium were differently responsive to immunohistochemical staining (MUC5AC- and MUC6-). Therefore, it is clear that the tall columnar mucinous epithelial cells with papillary proliferation and nulcear atypia are truly neoplastic rather than reactive or metaplastic. The immunohistochemical results of crowded small tubular structures were unexpected (CK20+ and increased Ki-67 labeling). It is supposed that this tubular structures are the primitive starting point of the IPN from the following facts. First, the tubular structures are located in the vertical center of the gallbladder wall. Second, the tubular structures showed increased proliferative activity (relatively high Ki-67 labeling).

Since the localized AMH has been known to have no strong association with gallbladder cancer, the gallstones and cholecystitis may be considered as a cause of the presenting IPN. However, we believe that in the present case, an IPN with high grade dysplasia (in situ carcinoma) arose from a localized AMH based on the following reasons: (1) the IPN was located and confined within the subserosa; (2) the mucosa did not show any neoplastic or reactive changes caused by stones; (3) RAS with smooth muscle hyperplasia was present

Table 3. Clinicopathologic features of in situ or invasive adenocarcinomas in a papillary configuration arising from and limited to Rokitansky-Aschoff sinus or adenomyomatous hyperplasia of the gallbladder

\begin{tabular}{lcccccccc}
\hline Sex & Age & $\begin{array}{c}\text { Tumor } \\
\text { location }\end{array}$ & $\begin{array}{c}\text { Intramural stones } \\
\text { within RAS }\end{array}$ & $\begin{array}{c}\text { Involvement of the } \\
\text { surface epithelium }\end{array}$ & $\begin{array}{c}\text { Intracystic } \\
\text { papillary fronds }\end{array}$ & $\begin{array}{c}\text { Stromal } \\
\text { invasion }\end{array}$ & $\begin{array}{c}\text { Subtype of } \\
\text { AMH }\end{array}$ & Study \\
\hline Male & 67 & Fundus & Yes & No & Yes & Yes & Segmental & Kawarada et al. ${ }^{5}$ (1986) \\
Male & 40 & Body & Yes & No & Yes & No & Segmental & Funabiki et al. ${ }^{6}$ (1993) \\
NA & NA & NA & NA & No & Yes & Yes & NA & Albores-Saavedra et al. (2004) $^{7}$ \\
NA & NA & NA & NA & No & Yes & Yes & NA & Albores-Saavedra et al. (2004) \\
Male & 77 & Fundus & Yes & No & Yes & No & No AMH & Terada ${ }^{7}$ (2008) \\
Male & 64 & Fundus & No & No & Yes & Yes & NA & Sato et al. ${ }^{9}$ (2016) \\
Female & 68 & Fundus & Yes & No & Yes & No & Localized & Present \\
\hline
\end{tabular}

RAS, Rokitansky-Aschoff sinuses; AMH, adenomyomatous hyperplasia; NA, not applicable. 
in the fundus; and (4) gradual transition from non-dysplastic to dysplastic cells was identified in the subserosal cystic epithelium not in the gallbladder mucosal epithelium.

Such cases have been rarely reported (Table 3 ). Only two of these cases described the image findings in detail. A 40-year-old male patient with early gallbladder cancer derived from a RAS revealed a bilocular gallbladder with an uneven soft tissue density area accompanied by high density spots on the fundus side on the computed tomography (CT) scan. ${ }^{6}$ A 64-year-old male patient with IPN with an associated mucinous adenocarcinoma arising in RAS of the gallbladder demonstrated a cystic mass protruding outward from the fundus with mild contrast enhancement in the cystic wall on portal venous phase on CT scan. ${ }^{9}$ Unfortunately, the presenting case showed gallstones only in the ultrasonography. IPN is radiologically missed in $10 \%$ of cases. ${ }^{11}$ Although detailed information cannot be obtained from the two cases described in one of these studies, all the patients showed an endophytic papillary intramural mass without mucosal involvement or an exophytic mass. In these cases, the level of stromal invasion varied and the AMH was of the segmental type or was not known. The follow-up period ranged from 4 months to 4 years and disease progression or local recurrence was not reported.

In summary, we reported a case of intraepithelial papillary mucinous neoplasm of the gallbladder that derived from and was limited to a localized AMH. This was found incidentally during organ harvesting for transplantation, and therefore careful examination was necessary to exclude invasive carcinoma.

\section{요 약}

만성담낭염에 흔히 동반되는 담낭의 선근종증은 육안적 형태에 따라 분절형, 국소형, 미만형의 세가지로 분류할 수 있다. 선근종증에서 드물게 담낭암의 전구성병변이나 담낭암이 발생하기도 하는데, 대부분 분절형 선근종증에서 기원하는 것으로 알려져 있다. 담낭암의 전구성병변 중 하나인 담낭내 유두모양종양은 담낭의 점막 상피에서 기원하여 내강 내로 자라면서 용종이나 유두종을 형성하는 것이 일반적이다. 이번
증례에서 담낭 점막의 용종이나 유두종을 형성하지 않고 근육층에 국한되어 있으면서 국소형 선근종증에서 유래한 담낭내유두모양종양 1 예를 보고하고자 한다.

국문 색인: 선근종성 증식증, 선근종증, 유두모양종양, 담낭

\section{Conflicts of Interest}

The authors have no conflicts to disclose.

\section{REFERENCES}

1. Albores-Saavedra J, Keenportz B, Bejarano PA, Alexander AA, Henson $D E$. Adenomyomatous hyperplasia of the gallbladder with perineural invasion: revisited. Am J Surg Pathol 2007;31:1598-1604.

2. Ootani T, Shirai Y, Tsukada K, Muto T. Relationship between gallbladder carcinoma and the segmental type of adenomyomatosis of the gallbladder. Cancer 1992;69:2647-2652.

3. Nabatame N, Shirai Y, Nishimura A, Yokoyama N, Wakai T, Hatakeyama K. High risk of gallbladder carcinoma in elderly patients with segmental adenomyomatosis of the gallbladder. J Exp Clin Cancer Res 2004:23:593-598.

4. Kim JH, Jeong IH, Han JH, et al. Clinical/pathological analysis of gallbladder adenomyomatosis; type and pathogenesis. Hepatogastroenterology 2010;57:420-425.

5. Kawarada Y, Sanda M, Mizumoto R, Yatani R. Early carcinoma of the gallbladder, noninvasive carcinoma originating in the RokitanskyAschoff sinus: a case report. Am J Gastroenterol 1986;81:61-66.

6. Funabiki T, Matsumoto S, Tsukada N, Kimura T, Yoshizaki S, Horibe Y. A patient with early gallbladder cancer derived from a RokitanskiAschoff sinus. Surg Today 1993;23:350-355.

7. Albores-Saavedra J, Shukla D, Carrick K, Henson DE. In situ and invasive adenocarcinomas of the gallbladder extending into or arising from Rokitansky-Aschoff sinuses: a clinicopathologic study of 49 cases. Am J Surg Pathol 2004;28:621-628.

8. Terada T. Gallbladder adenocarcinoma arising in Rokitansky-Aschoff sinus. Pathol Int 2008;58:806-809.

9. Sato R, Ando T, Tateno H, Rikiyama T, Furukawa T, Ebina N. Intracystic papillary neoplasm with an associated mucinous adenocarcinoma arising in Rokitansky-Aschoff sinus of the gallbladder. Surg Case Rep 2016;2:62.

10. Bosman FT, Carneiro F, Hruban RH, Theise ND. WHO classification of tumours of the digestive system. 4th ed. p207-271, Geneva, World Health Organization; 2010.

11. Adsay V, Jang $K T$, Roa JC, et al. Intracholecystic papillary-tubular neoplasms (ICPN) of the gallbladder (neoplastic polyps, adenomas, and papillary neoplasms that are $\geq 1.0 \mathrm{~cm}$ ): clinicopathologic and 
immunohistochemical analysis of 123 cases. Am J Surg Pathol 2012;36:1279-1301.

12. Adsay NV, Bagci P, Tajiri T, et al. Pathologic staging of pancreatic, ampullary, biliary, and gallbladder cancers: pitfalls and practical limitations of the current AJCC/UICC TNM staging system and opportunities for improvement. Semin Diagn Pathol 2012;29:127-141.
13. Williams I, Slavin G, Cox A, Simpson P, de Lacey G. Diverticular disease (adenomyomatosis) of the gallbladder: a radiological-pathological survey. Br J Radiol 1986;59:29-34.

14. Pang $L$, Zhang $Y$, Wang $Y$, Kong J. Pathogenesis of gallbladder adenomyomatosis and its relationship with early-stage gallbladder carcinoma: an overview. Braz J Med Biol Res 2018;51:e7411. 